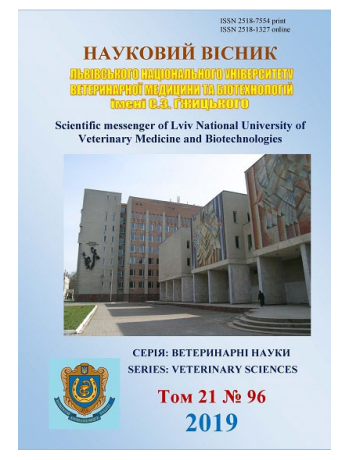

\author{
Науковий вісник Львівського національного університету \\ ветеринарної медицини та біотехнологій імені С.3. Гжицького. \\ Серія: Ветеринарні науки
}
Scientific Messenger of Lviv National University of Veterinary Medicine and Biotechnologies. Series: Veterinary sciences

\title{
The influence of Zinc and Manganese chelates (pantothenates) on some chicken broiler metabolism indicators
}

\author{
V.S. Sakara, A.Yu. Melnyk \\ Bila Tserkva National Agrarian University, Bila Tserkva, Ukraine
}

Article info

Received 16.10.2019

Received in revised form 17.11.2019

Accepted 18.11.2019

Bila Tserkva National Agrarian University, Bila Tserkva, pl. 8/1 Soborna, 09117 Ukraine. Tel.: +38-097-034-01-15 E-mail:v.sakara@outlook.com
Sakara, V.S., \& Melnyk, A.Yu. (2019). The influence of Zinc and Manganese chelates (pantothenates) on some chicken broiler metabolism indicators. Scientific Messenger of Lviv National University of Veterinary Medicine and Biotechnologies. Series: Veterinary sciences, 21(96), 134-140. doi: 10.32718/nvlvet9624

The article presents the results of the use of the vitamin-amino acid chelates (pantothenates) of Zinc and Manganese in order to study their effect on some indicators of avian metabolism. The studies were started on 14-day Cobb 500 broiler chickens in the poultry farm of the Bila Tserkva National Agrarian University Training and Production Center. For this purpose, 3 groups poultry were formed: two experimental ones (Zinc and Manganese chelates were fed to the main diet with water) and a control group (50 heads each). During the experiment (14, 21, 28 days), weighed chickens followed by blood sampling for biochemical study. In the group where the chelates were drunk at a dose of $0.2 \mathrm{ml} / \mathrm{l}$ of water over the next 14 days, there was a tendency to increase the absolute weight gain in broiler chickens to $943.0 \pm 25.94 \mathrm{~g}$ (770-1073), compared with the control -883.2 $\pm 24.64 \mathrm{~g}$ (740-1140). The bird, which was given chelates at a dose of $0,1 \mathrm{ml} / \mathrm{l}$ of water for 14 days, increased the content of total protein in the serum by $10.3 \%$ compared to the beginning of the study, and was $30.9 \pm 0.71 \mathrm{~g} / \mathrm{l}(P<0.001)$. In the second group (chelate dose of $0.2 \mathrm{ml} / \mathrm{l}$ water), this indicator increased by $11.2 \%$ and amounted to $30.2 \pm 0.82 \mathrm{~g} / \mathrm{l}(P<0.01)$. At the end of the experiment (28 days of cultivation), the albumin content in the blood of the birds of the first and second experimental groups was $18.6 \pm 0.36$ and $18.7 \pm 0.37 \mathrm{~g} / \mathrm{l}(P<0.001$ before the first selection). Manganese concentration in broiler chickens of the second experimental group on the 28th day was $3.6 \pm$ $0.28 \mathrm{\mu mol} / \mathrm{l}$ and was higher than the control $(2.7 \pm 0.25 \mu \mathrm{mol} / \mathrm{l} ; P<0.01)$. At doses of $0,1 \mathrm{ml} / \mathrm{l}$ of water $(1 \mathrm{st}$ experimental group), there was a tendency to increase the amount of this trace element in serum to $3.2 \pm$ $0.16 \mu \mathrm{mol} / \mathrm{l}(1.4-4,0)$. After 14 days of chelating, Zinc content in the serum of chickens of the first experimental group increased by $20 \%$ and amounted to $27.9 \pm 0.60 \mu \mathrm{mol} / \mathrm{l}$, in its second-concentration increased by $25.8 \%(28.3 \pm 0.76 \mu \mathrm{mol} / \mathrm{l} ; P<0.001)$ compared to the start of the experiment. Therefore, the use of the vitamin-amino acid chelates of Zinc and Manganese for 14 days at a dose of 0,1 and $0.2 \mathrm{ml} / \mathrm{l}$ of water contributed to the increase in weight gain, increase of total protein, Manganese and Zinc in the serum of broiler chickens.

Key words: broiler chickens, pantothenic acid, glycine, Zinc, Manganese, protein metabolism.

\section{Вплив хелатів (пантотенатів) Цинку та Мангану на деякі показники метаболізму курчат-бройлерів}

\author{
В.С. Сакара, А.Ю. Мельник
}

Білочерківський національний аграрний університет, м. Біла Церква, Украӥна

У статті наведено результати застосування вітамінно-амінокислотних хелатів (пантотенатів) Цинку та Мангану з метою вивчення їх впливу на деякі показники метаболізму птиці. Дослідження були розпочаті на 14-добових курчатах-бройлерах кросу Cobb 500 в умовах птахоферми навчально-виробничого ичентру Білочерківського НАУ. Для цьього сформовано 3 групи птиці: дві дослідні (до основного раџіону з водою отримували хелати Цинку та Мангану) та контрольна, по 50 голів у кожсній. Під час дослі- 
ду $(14,21,28$ доба) проводили зважування курчат з наступним відбором крові для біохімічного дослідження. У групі, де випоювали хелати в дозі 0,2 мл/л води упродовж наступних 14 діб відмічали тендениію до зростання абсолютного приросту маси тіла у курчат-бройлерів до 943,0 \pm 25,94 г (770-1073), порівняно з контролем - 883,2 $\pm 24,64$ г (740-1140). У птииі, якій задавали хелати в дозі 0,1 мл/л води впродовж 14 діб, збільшився вміст загального білка в сироватці крові на 10,3\% порівняно з початком дослідження, і становив 30,9 \pm 0,71 г/л (P<0,001). У другій групі (доза хелатів 0,2 мл/л води) цей показник підвищився на 11,2\% і складав 30,2 \pm 0,82 г/л (P < 0,01). По закінченні досліду (28-а доба вирощування) вміст альбумінів у крові птиці периої та другої дослідних груп становив 18,6 \pm 0,36 та 18,7 \pm 0,37 г/л (P < 0,001 до першого відбору). Концентрація Мангану у курчат-бройлерів другої дос-

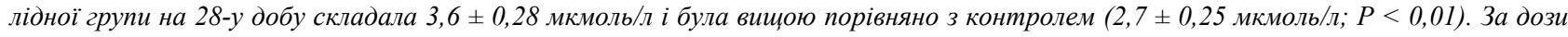
0,1 мл/л води (1-а дослідна група) відмічали тенденцію до збільшення кількості иього мікроелемента в сироватиі крові до 3,2 \pm 0,16 мкмоль/л (1,4-4,0). Після 14-добового випоювання хелатів вміст Цинку в сироватці крові курчат першої дослідної групи збіль-

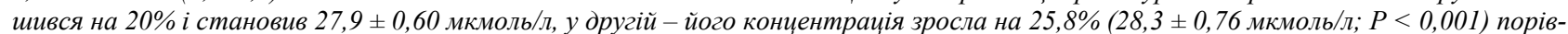
няно з початком досліду. Отже, застосування вітамінно-амінокислотних хелатів Цинку та Мангану упродовж 14 діб у дозі 0,1 та 0,2 мл/л води сприяло збільшенню приростів маси тіла, підвищенню загального білка, Мангану та Цинку в сироватці крові курчат-бройлерів.

Ключові слова: курчата-бройлери, пантотенова кислота, гліцин, Цинк, Манган, білковий обмін.

\section{Вступ}

Відсутність або дефіцит окремих з мікроелементів, а також порушення їх співвідношення в кормах призводить до зниження ефективності використання поживних речовин i, як наслідок, зменшення продуктивності, зростання захворюваності та передчасного вибракування (Richards et al., 2010; Caruk et al., 2017). Цинк та Манган відносяться до біотичних елементів і беруть активну участь у численних біохімічних процесах, що робить їх необхідними для оптимального росту і розвитку птиці. Зазвичай, мікроелементи додають до раціону у формі неорганічних солей (сульфатів або оксидів) (Zhao et al., 2010), проте їх абсорбція $з$ таких джерел обмежена, насамперед, через антагонізм у кормі та шлунково-кишковому тракті (Sun et al., 2012; Yenice et al., 2015). Засвоюваність неорганічних форм мікроелементів у сучасних преміксах для птиці мінімальна, що варіює в межах 5-20\%, тоді як в органічних (хелатні сполуки) - 80-90\% (Ellen et al., 2012). Мінеральні речовини мають надходити в організм птиці в оптимальних кількостях та співвідношеннях, залежно від потреби. Зазвичай мінеральному складу кормів приділяють недостатньо уваги, створюючи умови для виникнення хвороб, спричинених дефіцитом мікроелементів (Fedak et al., 2012).

Актуальність теми. Хелати являють собою особливу групу комплексних сполук, в яких іон металу пов'язаний 3 двома або більше атомами просторово орієнтованих функціональних груп на той же ліганд, зокрема, таких як лізин, гліцин, метіонін. Вони включають велику фізичну стабільність, що зменшує руйнування мікроелементів і вітамінів в окисненні кормів і збільшує їх засвоюваність (Ivanišinová et al., 2016). Sridhar et al. (2015) описує, що заміна 40 ppm Zn неорганічної форми на 30 ppm з органічного джерела збільшило концентрацію в сироватці крові фракцій глобулінів, активність лужної фосфатази та якість шкіри у курчат-бройлерів, порівняно з тими, кому згодовували корм із Цинку сульфатом. Результати досліджень (Kwiecień et al., 2017) показують, що додавання $\mathrm{Zn}$-гліцину до корму збільшило накопичення Zn i Cu в печінці та зменшило кількість Цинку, що виділяється 3 послідом. Додавання органічного Zn-Pro в корм збільшує накопичення Цинку в печінці курчатбройлерів. Його абсорбція 3 Zn-Pro комплексу є ви- щою, ніж у Zn-Gly i Zn-сульфату в зв'язку з різною силою комплексоутворення органічних кормових сполук (Ivanišinová et al., 2016). Манган в органічній формі має вищу ефективність, ніж неорганічний (Mnсульфат), а ліганд метіоніну краще сприяє абсорбції Мангану ніж гліцин (Olgun, 2017). Як джерело мікроелементів для птиці ефективно використовують хелати-proteinates (Stanaćev et al., 2014). De Marco et al. (2017) вказує на ефективність заміни 50\% неорганічних добавок на таку саму кількість органічних у вигляді хелатів гліцину. Додавання Цинку-метіоніну в дозі 80 мг/кг корму сприяє кращому розвитку імунних органів та імунної відповіді у курчат-бройлерів (Mohammadi et al., 2015). Тому, вдосконалення методів використання хелатів для покращення метаболізму в критичні періоди розвитку курчат-бройлерів $є$ однією $з$ актуальних тем сьогодення (Li et al., 2019).

Мета роботи - вивчити метаболізм Цинку та Мангану у сироватці крові курчат-бройлерів за використання різних доз $25 \%$ водного розчину вітамінно-амінокислотних хелатів (пантетонатів) Цинку та Мангану та їх вплив на обмін загального білка, альбумінів, загального Кальцію, неорганічного Фосфору, Магнію.

\section{Матеріал і методи досліджень}

Дослідження проведені у 2019 році на базі науково-дослідного інституту внутрішніх хвороб тварин, кафедри терапії та клінічної діагностики ім. B.I. Левченка та в умовах птахоферми навчальновиробничого центру Білоцерківського національного аграрного університету.

Для досліду було сформовано 3 групи - аналоги курчат-бройлерів кросу Cobb-500 14-добового віку: контрольна та дві дослідні по 50 голів у кожній 3 клінічними ознаками дефіциту Цинку та Мангану. Кров для дослідження відбирали по 20 зразків із кожної групи. Птицю перед початком експерименту досліджували клінічно.

Вітамінно-амінокислотні (пантетонати) кормові добавки Цинку (25\% розчин у воді змішаного хелатного комплексу 3 вмістом Цинку 3,0\%, гліцину 3,5\%, пантотенової кислоти 21,0\%) та Мангану (25\% розчин у воді змішаного хелатного комплексу з вмістом Мангану $2,6 \%$, гліцину 3,6\%, пантотенової кислоти 22,0\%) на 
основі гліцину та пантотенової кислоти (ТУ У 24.130931207-011-2007) експериментальної партії ПП "Кронос-Агро" змішували та задавали 3 водою 2 групам курчат-бройлерів 3 14-добового віку впродовж
14 діб (табл. 1). Годівлю птиці здійснювали згідно технологічної карти комбікормом власного виробництва: предстарт (0-10), старт (11-21), гроувер (22-35), із 36 доби і до забою - фінішер.

\section{Таблиця 1}

Схема досліду з комбінованим використанням вітамінно-амінокислотних хелатів Цинку та Мангану

\begin{tabular}{cl}
\hline Група птиці & \multicolumn{1}{c}{ Вік, діб } \\
\cline { 2 - 2 } Контрольна, $\mathrm{n}=50$ & Основний раціон \\
1-а дослідна, $\mathrm{n}=50$ & Основний раціон + випоювання з водою хелатів Mn та Zn у дозі 0,1 мл/л води \\
2-а дослідна, $\mathrm{n}=50$ & Основний раціон + випоювання з водою хелатів Mn та Zn у дозі 0,2 мл/л води \\
\hline
\end{tabular}

Відбір крові та зважування 14-добових курчатбройлерів проводили перед застосуванням хелатів, на 21-у добу та по завершенні експерименту (28-а доба). Кров для дослідження відбирали методом прижиттєвої пункції підкрилової вени (Kelly \& Alworth, 2013; Striha \& Il'chenko, 2017). Біохімічне дослідження крові проводили на біохімічному аналізаторі Stat Fax 1904+ з використанням реактивів НВП “Філісіт-Діагностика”. У сироватці крові визначали вміст загального білка (біуретовою реакцією), альбумінів (із бромкрезоловим зеленим), Кальцію загального (в реакції з кальцій-арсеназо-III), Фосфору неорганічного (з молібдатом амонію; UVваріант), Магнію (реакція 3 ксилідиловим синім). Дослідження вмісту Мангану та Цинку в сироватці крові птиці проводили методом атомно-абсорбційної спектрофотометрії на приладі Shimadzu AA-6650 (Onyshhenko et al., 2011). Дослід проводили відповідно до Закону України "Про захист тварин від жорстокого поводження” від 28.03.2006 р. та правил Європейської конвенції захисту хребетних тварин, які використовуються в експериментальних та інших наукових цілях від 13.11.1987 p. (Directive, 2010). Результати досліджень були статистично обраховані за допомогою програми Excel 2019.

\section{Результати та їх обговорення}

Курчата-бройлери на відміну від інших видів сільськогосподарської птиці мають високу інтенсивність росту, тому контроль приростів маси тіла є одним 3 важливих заходів під час вирощування (Вао et al., 2010; Caruk et al., 2017). Встановлено, що на початку дослідження маса тіла у курчат контрольної групи становила в середньому $225,6 \pm 6,58$ г, у першій та другій дослідних групах - 235,8 $\pm 3,58$ та $211,0 \pm$ 5,44 г, відповідно (табл. 2). Перед початком експерименту проведено клінічне дослідження курчатбройлерів. У 40\% птиці всіх груп спостерігали відставання в рості, скуйовдженість та ламкість 3 непропорційним ростом оперення, слизові оболонки блідорожевого забарвлення. У 17\% відмічали ознаки диспепсії. Після прийому препарату (28-а доба) курчатабройлери двох дослідних груп були активнішими, охоче поїдали корм та споживали воду, оперення у птиці щільно прилягало до тіла. У 2 голів першої дослідної групи спостерігали знижений апетит, скуйовдженість оперення та розлади травлення. У птиці контрольної групи 15 голів (30\%) мала виражену скуйовдженість оперення, блідість слизових оболонок, відставання у рості та діарею.

Після 14 діб випоювання вітамінноамінокислотних хелатів у курчат першої та другої дослідних груп маса тіла збільшилась, порівняно 3 початковим значенням на 683,2 і 732 г (74,3 та 77,6\%), за середніх значень $919,0 \pm 21,07$ та 943,0 $\pm 25,94$ г (P $<0,001)$, в контролі зросла на 657,6 г, що складало в середньому 883,2 $\pm 24,64$ г $(\mathrm{P}<0,001)$. У першій дослідній групі наприкінці досліду 5 голів (25\%) мали масу більше за 1000 г, менше 800 г було тільки в 1 курчати. В 35\% (7 голів) курчат-бройлерів другої дослідної групи маса тіла більша за 1000 г, а у 2 голів (10\%) нижче за 800 г. У контрольній групі тільки в 3 голів (15\%) маса тіла досягла 1 кг, а 25\% (5 голів) курчат навіть не набрали 800 г.

\section{Таблиця 2}

Динаміка маси тіла курчат-бройлерів за використання хелатів, $\mathrm{M} \pm \mathrm{m}$

\begin{tabular}{|c|c|c|c|c|}
\hline \multirow{2}{*}{ Вік, діб } & & \multicolumn{3}{|c|}{ Група } \\
\hline & & контрольна, $\mathrm{n}=20$ & 1-а дослідна, n = 20 & 2-а дослідна, $\mathrm{n}=20$ \\
\hline \multirow{2}{*}{14} & Lim & $186-290$ & $211-265$ & $174-274$ \\
\hline & $\mathrm{M} \pm \mathrm{m}$ & $225,6 \pm 6,58$ & $235,8 \pm 3,58$ & $211,0 \pm 5,44$ \\
\hline \multirow[b]{2}{*}{21} & Lim & 404-680 & 439-765 & $353-616$ \\
\hline & $\mathrm{M} \pm \mathrm{m}$ & $506,2 \pm 16,99$ & $543,3 \pm 19,52$ & $513,6 \pm 20,58$ \\
\hline \multirow{2}{*}{28} & Lim & $740-1140$ & $750-1140$ & $770-1073$ \\
\hline & $\mathrm{M} \pm \mathrm{m}$ & $883,2 \pm 24,64$ & $919,0 \pm 21,07$ & $943,0 \pm 25,94$ \\
\hline
\end{tabular}


Нами встановлено, що на початку експерименту вміст загального протеїну в сироватці крові курчатбройлерів 14-добового віку першої та другої дослідних груп складав, відповідно $27,7 \pm 0,59$ та $26,8 \pm 0,67$ г/л (норма - 29-38 г/л), в контролі - 28,7 $\pm 0,76$ г/л (табл. 3). На 21 добу (2 відбір крові) у першій та другій дослідних групах його концентрація становила 29,5 \pm 0,52 та 30,0 $\pm 1,35$ г/л, відповідно, що більше на 6,1 та $10,6 \%$ порівняно 3 показниками 1 відбору $(\mathrm{P}<0,05)$. По закінченні досліду вміст загального протеїну в сироватці крові курчат першої дослідної групи (доза хелатів складала 0,1 мл/л води) збільшився на $10,3 \%$, порівняно $з$ початком дослідження, i становив $31,0 \pm 0,71$ г/л $(\mathrm{P}<0,001)$, гіпопротеїнемію діагностували у 4 голів (20\%). У другій дослідній групі в середньому цей показник складав 30,2 \pm 0,82 г/л, що на $11,2 \%$ більше порівняно з результатами першого відбору крові $(\mathrm{P}<0,01)$, гіпопротеїнемію діагностували у 8 голів (40\%). У контрольній групі на 28 добу вміст загального протеїну у середньому становив $28,9 \pm 0,85$ г/л, вірогідно не змінився, порівняно 3 початком дослідження (P < 0,1). У 50\% (10 голів) діагностували гіпопротеїнемію, що на нашу думку, може бути спричинено недостатнім надходженням в організм протеїну з кормом, або ж порушенням його засвоєння.

\section{Таблиця 3}

Динаміка змін білкового обміну у курчат-бройлерів за використання хелатів, $\mathrm{M} \pm \mathrm{m}$

\begin{tabular}{|c|c|c|c|c|c|}
\hline & \multirow{2}{*}{ Вік, діб } & & \multicolumn{3}{|c|}{ Група } \\
\hline & & & контрольна, $\mathrm{n}=20$ & 1-а дослідна, $\mathrm{n}=20$ & 2-а дослідна, $\mathrm{n}=20$ \\
\hline \multirow{6}{*}{ 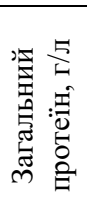 } & \multirow{2}{*}{14} & Lim & $22,1-35,7$ & $22,9-31,1$ & $20,7-31,9$ \\
\hline & & $\mathrm{M} \pm \mathrm{m}$ & $28,7 \pm 0,76$ & $27,7 \pm 0,59$ & $26,8 \pm 0,67$ \\
\hline & \multirow{2}{*}{21} & Lim & $25,1-33,6$ & $24,4-32,4$ & $20,4-43,6$ \\
\hline & & $\mathrm{M} \pm \mathrm{m}$ & $28,0 \pm 0,46$ & $29,5 \pm 0,52$ & $30,0 \pm 1,35$ \\
\hline & \multirow{2}{*}{28} & Lim & $23,6-35,4$ & $23,6-34,6$ & $24,4-35,2$ \\
\hline & & $\mathrm{M} \pm \mathrm{m}$ & $28,9 \pm 0,85$ & $31,0 \pm 0,71 * * *$ & $30,2 \pm 0,82 * *$ \\
\hline \multirow{6}{*}{ 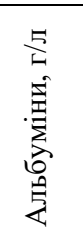 } & \multirow{2}{*}{14} & Lim & $13,6-22,35$ & $12,74-18,17$ & $12,87-21,93$ \\
\hline & & $\mathrm{M} \pm \mathrm{m}$ & $16,4 \pm 0,53$ & $15,4 \pm 0,29$ & $15,8 \pm 0,64$ \\
\hline & \multirow{2}{*}{21} & Lim & $14,41-21,35$ & $14,9-19,58$ & $14,01-23,93$ \\
\hline & & $\mathrm{M} \pm \mathrm{m}$ & $17,0 \pm 0,37$ & $17,2 \pm 0,27$ & $17,4 \pm 0,59$ \\
\hline & \multirow{2}{*}{28} & Lim & $14,8-24$ & $16,5-21,7$ & $14,8-22,3$ \\
\hline & & $\mathrm{M} \pm \mathrm{m}$ & $18,4 \pm 0,66^{*}$ & $18,6 \pm 0,36^{* * *}$ & $18,7 \pm 0,37 * * *$ \\
\hline
\end{tabular}

Примітки: *-P $<0,05 ; * *-\mathrm{P}<0,01 ; * * *-\mathrm{P}<0,001$ до початку показників першого відбору крові

У сироватці крові курчат-бройлерів контрольної групи на початку досліду вміст альбумінів становив $16,4 \pm 0,53$ г/л (норма 13-28 г/л), у першій та другій дослідних $-15,4 \pm 0,29$ та 15,8 \pm 0,64 г/л, відповідно (табл. 3). Після завершення застосування хелатів концентрація альбумінів в першій та другій дослідних групах збільшилась на 17,2 та $15,5 \%$, за середніх величин 18,6 $\pm 0,36$ і 18,7 $\pm 0,37$ г/л (Р <0,001 до першого відбору). У курчат контрольної групи діагностували збільшення цього показника на 10,9\% - 18,4 \pm 0,66 г/л ( $>0,05$ до початку досліду). Збільшення концентрації загального білка та альбумінів у сироватці крові курчат-бройлерів дослідних груп, на нашу думку, пов'язано з нормалізацією білоксинтезувальної функції печінки за рахунок властивостей Цинку та амінокислоти гліцину.

Кальцій відіграє надзвичайно важливу роль у метаболізмі птиці, зокрема він бере основну участь у формуванні кісткової тканини, нормальному функціонуванні нервової та розвитку серцево-судинної систем (Zlamanjuk, 2017). Встановлено, що на початку дослідження рівень загального Кальцію в сироватці крові контрольної групи становив $2,5 \pm 0,05$ ммоль/л $(1,88-$ $2,76)$, першої та другої дослідних - 2,5 $\pm 0,04(2,0-$ $2,74)$ і $2,5 \pm 0,04$ ммоль/л $(2,16-2,74)$, відповідно. Гіпокальціємію діагностували в $10 \%$ курчат-бройлерів iз кожної групи. По завершенні досліду його вміст у
$10 \%$ (2 гол.) контрольної групи був нижче норми (норма 2,25-3,0 ммоль/л) за середнього значення 2,6 \pm 0,05 ммоль/л $(\mathrm{P}<0,1)$. У першій та другій дослідних групах вміст загального Кальцію в середньому становив по 2,6 \pm 0,05 ммоль/л (Lim: 2,25-2,95; 2,36-3,07; $\mathrm{P}<0,1)$, гіпокальціємії не виявлено (табл. 4).

Фосфор в організмі птиці входить до складу нуклеїнових кислот, різних фосфопротеїдів, ферментів, відіграє важливу роль в обміні жирів, білків і вуглеводів, побудові кістяка (Caruk et al., 2017). Його концентрація в сироватці крові на початку експерименту в курчат першої та другої дослідних груп складала в середньому, відповідно, $2,4 \pm 0,10(1,82-3,37)$ та $2,4 \pm$ 0,07 (1,94-2,97) ммоль/л, у контрольній - коливалася у межах 1,83-2,89 і в середньому становила $2,4 \pm$ 0,06 ммоль/л (табл. 4). По закінченні експерименту змін в концентрації фосфору в сироватці крові не діагностували, в першій та другій групах середні значення становили $2,5 \pm 0,14(1,34-3,57)$ та $2,4 \pm 0,15$ $(1,27-3,73)$ ммоль/л. У контрольній групі на кінець досліду середній показник складав 2,4 $\pm 0,19(0,85-$ $3,67)$ ммоль/л (табл. 4). Результати дослідження показують, що застосування хелатів Цинку та Мангану протягом 14 діб не вплинуло негативно на рівень неорганічного фосфору в сироватці крові курчатбройлерів. 
Таблищя 4

Динаміка змін мінерального обміну у курчат-бройлерів за використання хелатів, $\mathrm{M} \pm \mathrm{m}$

\begin{tabular}{|c|c|c|c|c|c|}
\hline & \multirow{2}{*}{ Вік, діб } & & \multicolumn{3}{|c|}{ Група } \\
\hline & & & контрольна, $\mathrm{n}=20$ & 1-а дослідна, $\mathrm{n}=20$ & 2-а дослідна, $\mathrm{n}=20$ \\
\hline \multirow{6}{*}{ 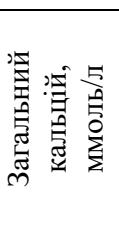 } & \multirow{2}{*}{14} & Lim & $1,88-2,76$ & $2,0-2,74$ & $2,16-2,74$ \\
\hline & & $\mathrm{M} \pm \mathrm{m}$ & $2,5 \pm 0,05$ & $2,5 \pm 0,04$ & $2,5 \pm 0,04$ \\
\hline & \multirow{2}{*}{21} & Lim & $1,85-3,8$ & $2,02-3,27$ & $2,21-3,7$ \\
\hline & & $\mathrm{M} \pm \mathrm{m}$ & $2,5 \pm 0,11$ & $2,5 \pm 0,09$ & $2,6 \pm 0,10$ \\
\hline & \multirow{2}{*}{28} & Lim & $2,19-3,02$ & $2,25-2,95$ & $2,36-3,07$ \\
\hline & & $\mathrm{M} \pm \mathrm{m}$ & $2,6 \pm 0,05$ & $2,6 \pm 0,05$ & $2,6 \pm 0,05$ \\
\hline \multirow{6}{*}{ 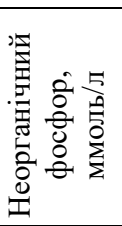 } & \multirow[b]{2}{*}{14} & Lim & $1,83-2,89$ & $1,82-3,37$ & $1,94-2,97$ \\
\hline & & $\mathrm{M} \pm \mathrm{m}$ & $2,4 \pm 0,06$ & $2,4 \pm 0,10$ & $2,4 \pm 0,07$ \\
\hline & \multirow{2}{*}{21} & $\operatorname{Lim}$ & $1,46-3,41$ & $1,71-2,99$ & $1,63-3,71$ \\
\hline & & $\mathrm{M} \pm \mathrm{m}$ & $2,4 \pm 0,14$ & $2,5 \pm 0,12$ & $2,4 \pm 0,12$ \\
\hline & \multirow{2}{*}{28} & Lim & $0,85-3,67$ & $1,34-3,57$ & $1,27-3,73$ \\
\hline & & $\mathrm{M} \pm \mathrm{m}$ & $2,4 \pm 0,19$ & $2,5 \pm 0,14$ & $2,4 \pm 0,15$ \\
\hline \multirow{6}{*}{ 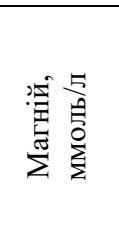 } & \multirow{2}{*}{14} & Lim & $1,1-1,42$ & $1,07-1,43$ & $1,06-1,42$ \\
\hline & & $\mathrm{M} \pm \mathrm{m}$ & $1,3 \pm 0,02$ & $1,2 \pm 0,03$ & $1,3 \pm 0,02$ \\
\hline & \multirow{2}{*}{21} & Lim & $1,12-1,5$ & $0,47-1,36$ & $0,47-1,44$ \\
\hline & & $\mathrm{M} \pm \mathrm{m}$ & $1,3 \pm 0,02$ & $1,2 \pm 0,05$ & $1,2 \pm 0,06$ \\
\hline & \multirow{2}{*}{28} & Lim & $0,91-1,29$ & $0,97-1,23$ & $0,96-1,23$ \\
\hline & & $\mathrm{M} \pm \mathrm{m}$ & $1,1 \pm 0,02 * * *$ & $1,1 \pm 0,02 * *$ & $1,1 \pm 0,02 * * *$ \\
\hline
\end{tabular}

Примітки: ** - $\mathrm{P}<0,01 ; * * *-\mathrm{P}<0,001$ до початку показників першого відбору крові

Магній $(\mathrm{Mg}) є$ одним із ключових елементів необхідних для росту і розвитку організму. Це четвертий найпоширеніший елемент у живих організмах (Shastak \& Rodehutscord, 2015). Концентрація магнію в сироватці крові 14-добових курчат контрольної групи знаходилась у межах 1,1-1,42 ммоль/л за середнього значення $1,3 \pm 0,02$ ммоль/л (див. табл. 4), в першій та другій дослідних групах $-1,2 \pm 0,03$ (1,07$1,43)$ та $1,3 \pm 0,02(1,06-1,42)$ ммоль/л. По закінченні досліду вміст магнію вірогідно знизився у всіх групах, зокрема в контрольній до $1,1 \pm 0,02$ ммоль/л (P $<0,001)$, у першій та другій дослідних групах $1,1 \pm 0,02$ ммоль/л $(\mathrm{P}<0,01$ та $\mathrm{P}<0,001)$, порівняно 3 початком дослідження (табл. 4). Подальше зменшення їх концентрації в сироватці крові пов'язано із технологічною зміною корму, покращенням стану слизової ниркових канальців та їх видільної функції.

Важливим мікроелементом у профілактиці перозу курчат-бройлерів є Манган (Adel Saeeda, 2014). Вiн $€$ одним 3 мікроелементів, який присутній у всіх тканинах, та є основою для нормального метаболізму амінокислот, ліпідів, білків та вуглеводів. Манган має ключове значення для регуляції імунної системи, клітинної енергії, травлення, розмноження та росту кісток (Tufarelli \& Laudadio, 2017). Недостатнє його надходження 3 комбікормом згодом може зумовити дефіцит Мангану у птиці, і як наслідок проблеми росту й розвитку кісток, а також порушення вуглеводного та ліпідного обмінів (Aschner \& Aschner, 2005). На початку проведення експерименту у 10 курчат (50\%) 14-добового віку контрольної групи його вміст у сироватці крові був нижчий за норму $(1,8-$ 5,5 мкмоль/л) і в середньому по групі становив $2,2 \pm 0,27$ мкмоль/л (1,1-6,2; див. табл.1). Низьку концентрацію Мангану діагностували в 11 голів першої дослідної групи (55\%) та в 10 голів (50\%) - у другій. Тобто на початку дослідження у сироватці крові 50\% курчат-бройлерів усіх груп діагностували недостатній рівень цього життєво важливого мікроелемента. Через 7 діб після початку застосування хелатів його вміст у сироватці крові першої та другої дослідних груп вірогідно збільшився, порівняно 3 початком експерименту, і становив, 2,9 $\pm 0,30$ та 3,5 \pm 0,33 мкмоль/л, відповідно ( $>0,01$; $\mathrm{P}<0,001)$. Також спостерігали зменшення кількості курчат в дослідних групах з низьким вмістом Мангану в крові до $5(25 \%)$ - у першій та 3 голів (15\%) - у другій. У контрольній групі відмічали тенденцію до збільшення концентрації Мангану в середньому до $2,7 \pm 0,26$ мкмоль/л $(0,9-5,0)$. По закінченні досліду його вміст у курчат-бройлерів яким випоювали хелати в дозі 0,2 мл/л води (2-а дослідна) складав 3,6 \pm 0,28 мкмоль/л, а різниця до контролю була вірогідною $-2,7 \pm 0,25$ мкмоль/л $(\mathrm{P}<0,01)$. У групі, де доза складала 0,1 мл/л води (1-а дослідна), спостерігали тенденцію до збільшення кількості Мангану в сироватці крові в середньому до $3,2 \pm 0,16$ мкмоль/л (1,4-4,0; Р < 0,1 до контролю). На нашу думку, незначна зміна вмісту Мангану в сироватці крові контрольної групі пов'язана $з$ особливістю фізіології утворення пера проте, ці дослідження потребують більш глибокого вивчення у віковому аспекті (рис. 1).

Цинк бере участь у процесах кальцифікації, активуючи лужну фосфатазу. За його дефіциту активність ферменту у хондроцитах епіфізарного хряща знижується, що спричиняє порушення остеогенезу (Slivinska et al., 2017). Концентрація Цинку на початку дослідження у всіх групах була низькою (норма 23,1-38,5 мкмоль/л), а його середнє значення по групах становило у контрольній - 22,3 $\pm 1,14$ мкмоль/л, у першій та другій дослідних $-21,0 \pm 1,31$ і 22,3 \pm 1,30 мкмоль/л (рис. 2). 


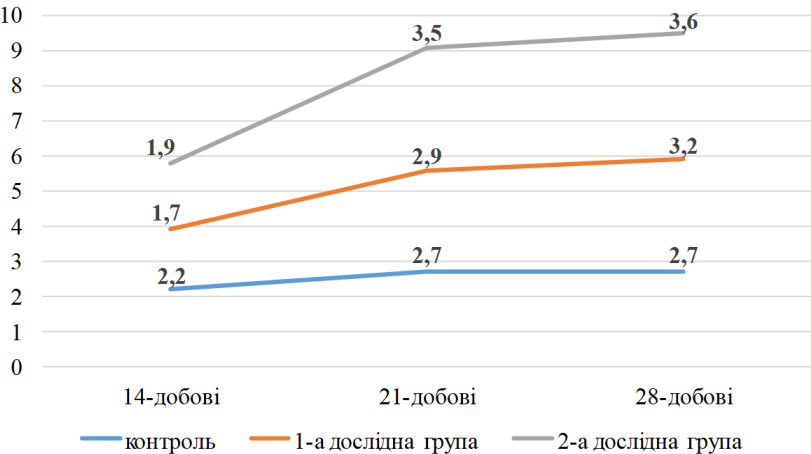

Рис. 1. Вміст Мангану у сироватці крові курчатбройлерів за використання хелатів, мкмоль/л

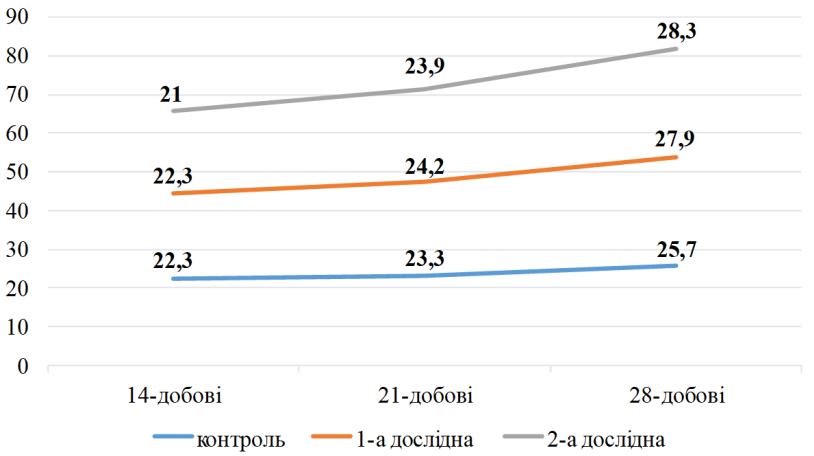

Рис. 2. Вміст Цинку у сироватці крові курчатбройлерів за використання хелатів, мкмоль/л

Дефіцит цинку діагностували у сироватці крові 50-60\% курчат-бройлерів. На 7 добу випоювання хелатів (2-й відбір крові) його вміст у другій дослідній групі мав тенденцію до збільшення за середнього значення $-23,9 \pm 0,56$ мкмоль/л, а в першій був вірогідно більший $-24,2 \pm 0,70$ мкмоль/л $(\mathrm{P}<0,05)$, порівняно 3 початком дослідження. Вміст цинку у крові курчат контрольної групи практично залишився без змін і становив 23,3 \pm 0,63 мкмоль/л. По закінченні досліду відмічали виражене збільшення концентрації Цинку в сироватці крові птиці першої дослідної групи (20\%), порівняно 3 початком дослідження, а його середнє значення становило 27,9 \pm 0,60 мкмоль/л (23,6-32,9 мкмоль/л; Р < 0,001). У другій групі його вміст збільшився на 25,8\% (порівняно 3 початком експерименту) за середнього значення - 28,3 \pm 0,76 мкмоль/л $(\mathrm{P}<0,001)$. Окрім цього, на прикінці досліду концентрація Цинку в курчат першої та другої дослідних груп була вірогідно більшою відносно контролю - 25,7 $\pm 0,78$ мкмоль/л $(\mathrm{P}<0,01)$.

Вірогідне збільшення мікроелементів Цинку та Мангану в сироватці крові курчат-бройлерів, на нашу думку, відбулося за рахунок того, що сполуки мікроелементів з лігандами амінокислот та вітамінів завдяки своїй формі краще абсорбуються ентероцитами кишечнику птиці. Таким чином відбувається більша засвоюваність організмом даних сполук та менше виділення з послідом (Vieira, 2008).

\section{Висновки}

Застосування хелатів упродовж 14 діб курчатамбройлерам дослідних груп сприяло покращенню загального стану, вони стали активніші, охоче поїдали корм та споживали воду, оперення у птиці блискуче, щільно прилягає до тіла. Клінічних ознак перозу не діагностували. Біохімічні дослідження показали, що застосування хелатів (пантотенатів) Цинку та Мангану протягом 14 діб в дозі 0,1 мл/л води сприяє збільшенню концентрації загального білка в сироватці крові на 10,3\% (30,9 $\pm 0,71$ г/л; $\mathrm{P}<0,001)$. У дозі 0,2 мл/л води - на 11,2\%, до 30,2 $\pm 0,82$ г/л (Р < 0,01). За рахунок фракцій альбумінів, вміст яких зріс до $18,6 \pm 0,36$ та 18,7 $\pm 0,37$ г/л $(\mathrm{P}<0,001)$. Додавання 3 водою хелатів у дозі 0,2 мл/л води сприяє збільшенню концентрації Мангану в сироватці крові курчатбройлерів до 3,6 \pm 0,28 мкмоль/л та Цинку на 25,8\% до $28,3 \pm 0,76$ мкмоль/л $(\mathrm{P}<0,001) .3$ випоювання в дозі 0,1 мл/л води спостерігається тенденція до збільшення Мангану - 3,2 $\pm 0,16$ мкмоль/л $(1,4-4,0)$ та Цинку на 20\% - 27,9 \pm 0,60 мкмоль/л.

Дякуємо приватному підприємству "Кронос-Агро" за надану можливість використовувати хелати (пантотенати) Zn i Mn для проведення досліджень.

\section{References}

Adel Saeeda, N. (2014). Impact of different levels of manganese and ascorbic acid on the growth performance of broiler chicks. International Proceedings of Chemical, Biological and Environmental Engineering, 64, 1-4. doi: 10.7763/IPCBEE. http://www.ipcbee.com/vol64/ 001-CEBCE2014-2-002.pdf.

Aschner, J.L., \& Aschner, M. (2005). Nutritional aspects of manganese homeostasis. Molecular Aspects of Medicine, 26(4-5), 353-362. doi: 10.1016/j.mam.2005.07.003.

Bao, Y.M., Choct, M., Iji, P.A., \& Bruerton, K. (2010). Trace mineral interactions in broiler chicken diets. British Poultry Science, 51(1), 109-117. doi: 10.1080/00071660903571904.

De Marco, M., Zoon, M.V., Margetyal, C., Picart, C., \& Ionescu, C. (2017). Dietary administration of glycine complexed trace minerals can improve performance and slaughter yield in broilers and reduces mineral excretion. Animal Feed Science and Technology, 232, 182-189. doi: 10.1016/j.anifeedsci.2017.08.016.

Directive. (2010). Directive 2010/63/EU of the european parliament and of the council of 22 September 2010 on the protection of animals used for scientific purposes. L 276/33. 20.10.2010. https://eurlex.europa.eu/LexUriServ/LexUriServ.do?uri=OJ:L:2 010:276:0033:0079:en:PDF

Ellen, B.B., Merca, F.E., Angeles, A.A., Acda, S.P., \& Luis, E.S. (2012). Effects of supplementing diets with amino acid chelates of Copper, Zinc, Manganese and Iron on the performance of broilers. Philipp J Vet Anim Sci, 38(1), 1-10.

Ivanišinová, O., Grešáková, L., Ryzner, M., Ocel’ová, V., \& Čobanová, K. (2016). Effects of feed 
supplementation with various zinc sources on mineral concentration and selected antioxidant indices in tissues and plasma of broiler chickens. Acta Veterinaria 85(3), 285-291. doi: $10.2754 /$ avb201685030285.

Kelly, L.M., \& Alworth, L.C. (2013). Techniques for collecting blood from the domestic chicken. Lab Animal, 42(10), 359-361. doi: 10.1038/laban.394.

Kwiecień, M., Winiarska-Mieczan, A., Milczarek, A., \& Klebaniuk, R. (2017). Biological response of broiler chickens to decreasing dietary inclusion levels of zinc glycine chelate. Biological Trace Element Research, 175(1), 204-213. doi: 10.1007/s12011-016-0743-y.

Li, L., Abouelezz, K.F.M., Gou, Z., Lin, X., Wang, Y., Fan, Q., \& Jiang, Z. (2019). Optimization of dietary zinc requirement for broiler breeder hens of chinese yellow-feathered chicken. Animals, 9(7), 472. doi: 10.3390/ani9070472.

Mohammadi, V., Ghazanfari, S., MohammadiSangcheshmeh, A., \& Nazaran, M.H. (2015). Comparative effects of zinc-nano complexes, zincsulphate and zinc-methionine on performance in broiler chickens. British Poultry Science, 56(4), 486493. doi: 10.1080/00071668.2015.1064093.

Olgun, O. (2017). Manganese in poultry nutrition and its effect on performance and eggshell quality. World's Poultry Science Journal, 73(01), 45-56. doi: 10.1017/S0043933916000891.

Richards, J.D., Zhao, J., Harrell, R.J., Atwell, C.A., \& Dibner, J.J. (2010). Trace Mineral Nutrition in Poultry and Swine. Asian-Australasian Journal of Animal Sciences, 23(11), 1527-1534. doi: 10.5713/ ajas.2010.r.07.

Shastak, Y., \& Rodehutscord, M. (2015). A review of the role of magnesium in poultry nutrition. World's Poultry Science Journal, 71(01), 125-138. doi: 10.1017/S0043933915000112.

Slivinska, L., Demydjuk, S., Shcherbatyy, A., Fedorovich, V., \& Tyndyk, I. (2017). Etiologija ta kliniko-biohimichni pokaznyky krovi za alimentarnoi osteodystrofii koriv. [Etiology of this clinicalbiochemical index of the roof for alimentary osteodystrophy of the roots]. Scientific Messenger of LNU of Veterinary Medicine and Biotechnologies, 19(73), 79-83. doi: 10.15421/nvlvet7317 (in Ukrainian).

Sridhar, K., Nagalakshmi, D., \& Rama Rao, S.V. (2015). Effect of graded concentration of organic zinc (zinc glycinate) on skin quality, hematological and serum biochemical constituents in broiler chicken. Indian Journal of Animal Sciences, 85(6), 643-648.

Stanaćev, V.S., Milošević, N., Stanaćev, V.Ž., Puvača, N., Milić, D., \& Pavlovski, Z. (2014). Chelating forms of microelements in poultry nutrition. World's Poultry Science Journal, 70(01), 105-112. doi: 10.1017/S0043933914000099.
Sun, Q., Guo, Y., Li, J., Zhang, T., \& Wen, J. (2012). Effects of methionine hydroxy analog chelated $\mathrm{cu} / \mathrm{mn} / \mathrm{zn}$ on laying performance, egg quality, enzyme activity and mineral retention of laying hens. The Journal of Poultry Science, 49(1), 20-25. doi: 10.2141/jpsa.011055.

Tufarelli, V., \& Laudadio, V. (2017). Manganese and its role in poultry nutrition: an overview. Journal of Experimental Biology and Agricultural Sciences, 5(6), 749-754. doi: 10.18006/2017.5(6).749.754.

Vieira, S.L. (2008). Chelated minerals for poultry. Brazilian Journal of Poultry Science, 10(4), 73-79. doi: 10.1590/S1516-635X2008000200001.

Yenice, E., Mizrak, C., Gültekin, M., Atik, Z., \& Tunca, M. (2015). Effects of organic and inorganic forms of manganese, zinc, copper, and chromium on bioavailability of these minerals and calcium in latephase laying hens. Biological Trace Element Research, 167(2), 300-307. doi: 10.1007/s12011-0150313-8.

Zhao, J., Shirley, R. B., Vazquez-Anon, M., Dibner, J.J., Richards, J.D., Fisher, P., Giesen, A.F. (2010). Effects of chelated trace minerals on growth performance, breast meat yield, and footpad health in commercial meat broilers. The Journal of Applied Poultry Research, 19(4), 365-372. doi: 10.3382/japr.200900020.

Striha, M., \& Il'chenko, M. (2017). Innovacijni rozrobky universytetiv i naukovyh ustanov MON Ukrainy. [Innovative development of universities and scientific institutions of the Ministry of Education and Science of Ukraine]. Instytut obdarovanoi dytyny NAPN Ukrainy, Kyiv (in Ukrainian).

Zlamanjuk, L.M. (2017). Vplyv riznyh rivniv kal'ciju ta fosforu u kombikormah na mineral'nyi sklad skeletu japons'kyh perepeliv. [The influence of different rivniv calcium and phosphorus in combines on the mineral harmony of the skeleton of Japanese perepeliv]. Ukrainan Jornal of Ecology, 7(2), 14-18. doi: 10.15421/201715 (in Ukrainian).

Onyshhenko, G.G., Zajceva, N.V., \& Ulanova, T.S. (2011). Kontrol' soderzhanija himicheskih soedinenij i jelementov $\mathrm{v}$ biologicheskih sredah: rukovodstvo. [Control of the content of chemical compounds and elements in biological environments: leadership]. Perm': Onishhenko G.G. (in Russian).

Fedak, N.M., Vovk, Ja.S., Chumachenko, S.P., \& Dushara, I.V. (2012). Mineral"ni rechovyny v godivli sil"s"kogospodars"kyh tvaryn. [Mineral substances in farm animal feeds]. Peredgirne ta girs'ke zemlerobstvo i tvarinnictvo, 1(54), 128-135 (in Ukrainian).

Caruk, L.L., Berezhnjuk, N.A., \& Chornolata, L.P. (2017). Balans mineral'nyh rechovyn u organizmi kurchat-brojleriv. [Balance of mineral substances in the body of broiler chickens]. Agrarna Nauka ta Harchovi Tehnologii, 2(96), 111-117 (in Ukrainian). 